\title{
FORMATION OF ARTISTIC-AESTHETIC COMPETENCE MEANS OF DECORATIVE AND CONSUMER ART: CONTENT AND STRUCTURE OF PHENOMENON
}

\author{
ФОРМУВАННЯ ХУДОЖНЬО-ЕСТЕТИЧНОЇ \\ КОМПЕТЕНТНОСТІ ЗАСОБАМИ \\ ДЕКОРАТИВНО-УЖИТКОВОГО МИСТЕЦТВА: \\ ЗМІСТ I СТРУКТУРА ФЕНОМЕНУ
}

\section{Zuziak Tatyana ${ }^{1}$ \\ Marushchak Oksana ${ }^{2}$}

DOI: https://doi.org/10.30525/978-9934-571-78-7_18

\begin{abstract}
In the conditions of creating a national system of education that will promote the development of personal competences on the basis of culture and art of the Ukrainian people, folk traditions, attracting the younger generation to the achievements of spiritual culture, the issue of formation of future artistic and aesthetic competence by arts and craftsmen becomes a matter of urgency. The subject of research is the process of formation of students of educational institutions of higher education of artistic and aesthetic competence by means of decorative and applied arts. The purpose of the study is to determine the theoretical foundations of the formation of a future teacher of artistic and aesthetic competence by means of decorative and applied arts. To achieve the research goal and for solution of the tasks was to use a set of theoretical research methods: the analysis of philosophical, psychological, pedagogical, methodological and special literature, as well as analysis, synthesis, abstraction, systematization of theoretical data, comparative analysis of the dissertation pa-pers in order to clarify the essence the concept of «professional competence of the teacher»; substantiation of the content and definition of the structure of the artistic and aesthetic competence of the teacher. The article analyzes the notion of competence as an integrative
\end{abstract}

\footnotetext{
${ }^{1} \mathrm{PhD}$ of Art history, Doctor of Science, Associate Professor, Associate Professor in Department of Technological Education, Economics and Life Safety, Vinnytsia State Mykhaylo Kotsybynskiy Pedagogical University, Ukraine

${ }^{2} \mathrm{PhD}$ of Pedagogical Sciences, Associate Professor, Associate Professor in Department of Technological Education, Economics and life Safety,

Vinnytsia State Mykhaylo Kotsybynskiy Pedagogical University, Ukraine
} 
qualification of the personality of the teacher, which characterizes his ability to perform pedagogical activity using of the integration of theoretical knowledge, practical skills, experience, values and significant personal qualities, measure and the main criterion for its compliance with its requirements. Artistic and aesthetic competence is defined as a professional-personal multidimensional phenomenon, which has a meta-structure and is characterized by the ability to create own works of decorative and applied arts, readiness to perceive the achievements of the world and domestic folk art, which is based on the awareness of folk culture and creativity, artistic taste, artistic knowledge and judgmental judgments. The artistic and aesthetic competence of a future teacher in the field of decorative arts as a personal entity is a single, integral structure. It has the main components: cognitive (the perception of decorative art as a social phenomenon and a constantly developing system; awareness of the connection of the decorative and utilitarian art with thinking, culture and social development of the people), motivational-value (the presence of motives, goals, needs, values, reflects the motivated personality to the development, preserved I am an extension of the traditions of my own ethnic group), activity-practical (the ability of the individual to know and preserve the national traditions of his ethnic group, as well as the practical and practical realities of their reproduction and creative transfer on the basis of the acquired knowledge and skills; to use existing professional knowledge, skills and abilities for realization tasks of professional activity), reflexive (person's ability to self-assess the attitude to the artistic traditions of one's and other ethnic groups, ability to analyze the course and results of their own practical activities, objective to evaluate himself, his level of artistic skill), communicative (the ability of the individual to self-communicate in the knowledge of the traditions of decorative and applied arts and to artistic dialogue with representatives of his and other ethnic groups on the basis of tolerance, mutual understanding, mutual respect in the process of knowledge of folk traditions), aesthetic (the integrator of the rest components in the process of mastering the traditions of decorative and applied arts). The success and effectiveness of the formation of artistic and aesthetic competence depends on a set of adequate principles, a functional orientation of teaching, methods and techniques, means and pedagogical conditions, in which training is organized. Therefore, we can see the prospects for further research in determining the pedagogical conditions, considering pedagogical technologies for the formation of artistic and aesthetic competence of future teachers by means of decorative and applied art. 


\section{1. Ветуп}

Народне декоративно-ужиткове мистецтво набуло визнання в Україні та за кордоном. У нинішньому світі, коли активно відбуваються глобалізаційні процеси, які нівелюють особливості національних культур, саме через народну культуру, народну творчість, народне мистецтво народи світу є цікавими для чужоземців своєю самобутністю й несхожістю на інших [13, с. 96]. Тому в умовах сьогодення особливо актуальною $є$ проблема відродження українських народних ремесел. Реалізація цього завдання значною мірою покладається на сучасну шкільну та позашкільну освіту.

Саме загальноосвітній навчальний заклад залишається основним соціальним інститутом, який надає дітям повну загальну середню освіту, вирішує завдання розвитку та виховання учнів. Головною метою загальноосвітньої школи стає переосмислення, переорієнтація та вплив на формування високоморальної громадської позиції, національної свідомості, потягу до прекрасного, важливу роль у досягненні якої відіграє декоративно-ужиткове мистецтво [16, с. 221]. Звернення до глибинних пластів народних ремесел і промислів - тисячолітнього доробку нашого народу, в якому зафіксовані духовність, обдарування, мистецький хист українців; живих свідчень безпосередніх носіїв досвіду чи їхніх нащадків; прилучення обдарованої молоді до традиційних видів декоративно-ужиткового мистецтва українців, створюють підгрунтя для розвитку іiі духовного і матеріального світу.

В умовах становлення української держави одним 3 найважливіших за-вдань є створення національної системи освіти, яка сприятиме розвитку компетентностей особистості на основі культури та мистецтва українського народу, народних традицій, залученню молодого покоління до надбань духовної культури [17, с. 229]. Важливого значення набуває проблема науково обгрунтованої системи професійної підготовки майбутнього вчителя в галузі декоративно-ужиткового мистецтва, яка грунтується на врахуванні сучасних вітчизняних і світових тенденцій у розвитку педагогічної освіти, перспективних духовно-творчих естетичних орієнтацій. У цьому контексті однією 3 основних складових професіоналізму майбутнього вчителя є художньо-естетична компетентність, яка формується лише під час художньо-естетичної діяльності. Як слушно зазначає В. Лутаєнко, мистецтво «розвиває, передусім, естетичний бік мислення», а «естетика 
мислення безпосередньо пов'язана зі ступенем участі людини в художній творчості й сприйняттям їі наслідків» [14, с. 214].

Актуальність проблеми формування професійної компетентності майбутнього вчителя на сучасному етапі розвитку професійної освіти зросла та їі вивчення помітно активізувалося за останні роки, зокрема модернізація освіти на компетентнісній основі досліджена в працях В. Байденка, В. Болотова, Р. Гуревича, С. Демченка, Е. Зеєра, I. Зимньої, М. Кадемії, В. Краєвського, Н. Кузьміної, А. Маркової, О. Овчарук, О. Пометун, А. Хуторського, В. Шахова та ін. Художньо-естетична компетентність особистості $є$ предметом досліджень Л. Масол, Н. Миропольської, Г. Падалки, Л. Рапацької, О. Рудницької, Т. Суслової, О. Шевнюк, О. Щолокової та ін. Питання мистецької освіти та підготовки фахівців відповідних дисциплін розглядали О. Дем'янчук, Л. Кондрацька, В. Орлов, О. Отич, В. Радкевич та ін.

Науковці Б. Асаф’єв, К. Абульханова-Славська, Г. Айзенк, Л. Дорфман, Є. Крупнік, Дж. Купчик, Г. Леонард, О. Леонтьєв, Д. Леонтьєв, В. Медушевський, О. Мелік-Пашаєв, С. Назайкінський, В. Петров, А. Сохор та ін. у своїх дослідженнях різнобічно розглядали феномен сприйняття мистецтва. Естетичний вплив мистецтва на формування особистості досліджено Д. Антоновичем, Л. Виготським, М. Гончаренком, Н. Джидар'ян, В. Зінченком, О. Киричуком, Г. Костюком, О. Леонтьєвим, К. Платоновим, Б. Тепловим, Д. Узнадзе, Б. Юсовим, П. Якобсоном та ін. Окремі питання декоративно-ужиткового мистецтва неодноразово знаходили своє відображення у працях науковців, зокрема С. Антонович, К. Духанін обгрунтували підходи до класифікації видів декоративно-ужиткового мистецтва; О. Рудницька, М. Каган, Р. Захарчук-Чугай охарактеризували функції декоративно-ужиткового мистецтва. Про могутній психолого-педагогічний і виховний потенціал народних художніх ремесел, їх просвітницький та культурний вплив на особистість свідчать дослідження С. Антоновича, А. Аронова, О. Єнтіс, М. Кагана, Н. Кузан, Т. Мацейків, В. Мусієнка, Н. Ничкало, Л. Оршанського, Л. Савки, В. Титаренко, С. Чебоненка та ін. Суттєвою $\epsilon$ позиція сучасних авторів (Д. Лихачов, І. Ляшенко, В. Москалець), які відстоюють право особистості на виховання з першоджерел національних традицій.

Незважаючи на те, що в теоретичних дослідженнях $є$ чимало напрацювань $з$ проблеми формування художньо-естетичної компе- 
тентності, можна констатувати, що педагогічний та змістовно-методичний аспекти формування у майбутніх учителів художньо-естетичної компетентності засобами декоративно-ужиткового мистецтва залишаються недостатньо дослідженими. Відтак, актуальність порушеної проблеми, складність загальнокультурної ситуації в Україні, об'єктивна потреба у постійному розвитку та оновленні професійної компетентності педагогів зумовили вибір теми статті.

Мета дослідження полягає у визначенні теоретичних основ формування у майбутнього вчителя художньо-естетичної компетентності засобами декоративно-ужиткового мистецтва. Відповідно до сформульованої мети визначені завдання дослідження: з'ясувати сутність поняття «професійна компетентність педагога»; обгрунтувати зміст художньо-естетичної компетентності педагога в галузі декоративно-ужиткового мистецтва; визначити структуру художньо-естетичної компетентності.

Для досягнення мети дослідження, розв'язання поставлених завдань ви-користовувався комплекс теоретичних методів дослідження: аналіз філософської, психологічної, педагогічної, методичної та спеціальної літератури, а також аналіз, синтез, абстрагування, систематизація теоретичних даних, порівняльний аналіз дисертаційних робіт з метою з'ясування сутності поняття «професійна компетентність педагога»; обгрунтування змісту, визначення структури художньо-естетичної компетентності педагога.

\section{2. Компетентність як інтегративна характеристика особистості педагога}

Вирішальною умовою та показником успішності людини в житті, у цілому, та у професійній діяльності, зокрема, нині стає ії компетентність. Знання та досвід у певній галузі забезпечують оволодіння інтелектуальним і фізичним інструментарієм певної діяльності.

Сутнісні ознаки компетентності особистості в наслідок зміни світу, вимог до «успішного дорослого» постійно змінюються; мають діяльнісний характер узагальнених умінь у поєднанні з предметними уміннями і знаннями в конкретних галузях (ситуаціях); виявляються в умінні здійснювати вибір, виходячи з адекватної оцінки себе в конкретній ситуації; пов'язані з мотивацією на неперервну самоосвітню діяльність. Компетентність характеризується багатофункціональні- 
стю, багатомірністю, надпредметністю, дієвістю, універсальністю, об'ємністю, інтелектуальною насиченістю, соціальністю.

Структурними компонентами компетентності можна вважати знання, уміння й навички та ціннісне ставлення. Значущість знань у структурі компетентності очевидна 3 огляду на те, що з одного боку, вони є базою для формування умінь і навичок, а з іншого - існує особливий вид знань - про способи діяльності, представлений у формі правил, пам'яток, алгоритмів тощо, який забезпечує процесуальний аспект навчання [18, с. 424-425].

Однак компетентність не зводиться лише до знань, умінь, навичок, оскі-льки знати, як виконувати ту чи іншу діяльність або вміти іiі виконувати, ще не гарантує бажання працювати, творчого ставлення до роботи. Компетентність «виводить метарівень, універсальний, що в інтегрованому вигляді представляє освітні результати, які досягаються не лише засобами освіти, а й соціальної взаємодії в міжособистісному й інституційному культурному контексті» [4, с. 47]. У зв'язку з цим третьою складовою компетентності особистості визнано формування ціннісного ставлення до процесу та результату праці. Ціннісне ставлення вчені розглядають як емоційне ставлення людини до певних об'єктів: норм, явищ, процесів, предметів тощо. Отже, йдеться про два аспекти проблеми: по-перше, про виховання системи цінностей; по-друге, про розвиток афективної сфери особистості (емоцій, почуттів тощо) [18, с. 425].

Зазначена кількість структурних компонентів компетентності $\epsilon$ необхід-ною, але, на нашу думку, недостатньою. Необхідною передумовою повноцінного навчання, а відтак і саморозвитку, самореалізації, постає формування рефлексії, яка дає змогу сформулювати (в разі потреби і скорегувати) мету діяльності, вибрати раціональні способи досягнення цієї мети, спрогнозувати результати тощо. Дослідник А. Хуторський зазначає, що, якщо фізичні органи чуття для людини - джерело зовнішнього досвіду, то рефлексія - джерело досвіду внутрішнього, спосіб самопізнання, необхідний інструмент мислення [24, с. 113].

Таким чином, компетентність - це синтез знань, умінь і навичок, емоційно-ціннісного ставлення та розгорнутої рефлексії.

Компетентність має особистісний характер і належить до діяльнісного компоненту освіти; вона багатовимірна (охоплює всі основні 


\section{Chapter «Pedagogical sciences»}

групи особистісних якостей); не зводиться до конкретних знань, умінь і навичок, попредметно сформованих у межах окремих дисциплін навчального плану закладу вищої освіти, а становить єдність знань і досвіду, спрямованих на успішну діяльність; вона метапредметна або міжпредметна, тобто через окремі елементи або цілісно відображається у різних навчальних предметах і освітніх галузях; багатофункціональна, оскільки дає змогу студентові вирішувати проблеми з різних сфер життя; характеризується соціальністю, системністю, ситуативністю, інтегративністю і практико-орієнтованістю; визначає готовність і мотиваційну здатність до вирішення не тільки типових завдань, а й проблем високого ступеня складності та невизначеності в професії, а також соціальних і особистісних завдань; формується і розвивається на основі компетенцій в органічній єдності з ціннісними орієнтаціями людини за умови iï змотивованості, актуалізації емоційно-вольової сфери та саморегуляції.

У свою чергу, у роботах педагогів-дослідників поняття «професійна компетентність» розглядається в контексті відповідної виконавської діяльності; розуміється як важливе новоутворення особистості, що інтегрує різні якості та властивості людини; характеризує ступінь підготовленості людини до професійної діяльності та характер ії здійснення; формується під час засвоєння людиною відповідної професійної діяльності.

Професійна компетентність визначається, головним чином, рівнем про-фесійної освіти, досвідом та індивідуальними здібностями людини, іiі прагненнями до безперервного самовдосконалення й самоосвіти, творчим ставленням до справи. Таким чином, поняття «професійна компетентність» нерозривно пов'язано із саморозвитком, самоосвітою особистості [2, с. 20].

Розглядаючи зміст професійної компетентності фахівців, варто відзначити складну, динамічну систему мотивів, особистісних помислів і цілей, що постійно розвивається. Вона містить індивідуально вироблені стратегії, засоби орієнтації у дійсності та підходи щодо вирішення завдань і включає такі компоненти: компетентність діяльності, спілкування та саморозвитку особистості фахівця як основу всієї інтегральної компетентності; професійну творчість діяльності, що включає спрямованість на системний пошук засобів та прийомів вирішення проблем професійної діяльності; системне та модельне мислення як 
необхідну умову організації та здійснення управління при вирішенні складних нестандартних завдань; конкретно-предметні знання, що $є$ підгрунтям формування компетентності; праксеологічну, рефлексивну та інформаційну озброєність у процесі вирішення різних проблем професійної діяльності $[1 ; 5]$.

Незважаючи на наявне нині різноманіття думок щодо трактування поняття професійної компетентності педагога, можна констатувати, що більшість авторів розглядають її як мету освіти, професійної підготовки, і як проміжний результат, що характеризує стан фахівця, який здійснює свою професійну діяльність. В існуючих визначеннях вона характеризується ефективним використанням здібностей, що дозволяє плідно здійснювати професійну діяльність згідно з вимогами робочого місця; володінням знаннями, уміннями та здібностями, необхідними для роботи за фахом за умов одночасної автономності і гнучкості під час рішення професійних проблем; розвиненою співпрацею з колегами і професійним міжособистісним середовищем; інтегрованим поєднанням знань, здібностей та установок, оптимальних для виконання трудової діяльності в сучасному середовищі; здатністю робити що-небудь добре, ефективно в широкому форматі контекстів з високим ступенем саморегулювання, саморефлексії, самооцінки; швидкою, гнучкою й адаптивною реакцією на динаміку обставин і середовища.

Таким чином, під професійною компетентністю педагога будемо розуміти його здатність до виконання педагогічної діяльності на основі інтеграції теоретичних знань, практичних умінь, досвіду, цінностей і значущих особистісних якостей, міру й основний критерій відповідності їі вимогам.

\section{3. Зміст художньо-естетичної компетентності}

Одним 3 основних завдань професійної підготовки майбутнього вчителя в галузі декоративно-ужиткового мистецтва є стимулювання емоційного розвитку, художнього мислення, активізація творчого потенціалу через засвоєння різних видів художньої та прикладної діяльності; створення умов для широкої базової освіти як основи професійної мобільності; оволодіння системою поглядів, згідно з якими професійні знання спрямовуються на формування особистісної культури, ціннісної свідомості майбутнього фахівця. У цьому контексті основною складовою професійної компетентності педагога є худож- 
ньо-естетична компетентність, яка визначає рівень володіння знаннями, уміннями й навичками на основі розвиненого образного мислення та практичної творчої діяльності, що виявляється в здатності виражати художній задум в образній формі художніми та декоративними засобами.

Існує чимало визначень художньо-естетичної компетентності. Науковці визначають художньо-естетичну компетентність як систему внутрішніх засобів регуляції художньо-естетичних дій, в яку безпосередньо входять художньо-естетичні знання, вміння і досвід, естетична орієнтованість, заснована на знаннях, досвіді особистості і вільному володінні художньо-естетичними засобами $[15$, с. 41$]$; обізнаність у галузі мистецтва, прагнення та здатність реалізувати на практиці свій художньо-естетичний потенціал для одержання власного неповторного результату творчої діяльності, де під художньо-естетичним потенціалом розуміється: певний обсяг культурно-історичних і художньо-естетичних знань; уміння та навички художньо-естетичного сприймання, аналізу й інтерпретації творів мистецтва відповідно до авторського задуму, розуміння єдності форми та змісту; готовність особистості до художньо-творчої реалізації, самостійного пізнання мистецтва, естетичної оцінки творів мистецтва [19, с. 72]; сукупність художніх інтересів, смаків, потреб, ідеалів та естетичних ціннісних орієнтацій у галузі мистецтва, художньо-образного мислення, опанування мовами різних видів мистецтва, здатність бути слухачем, глядачем, читачем і творцем, готовність сприймати, інтерпретувати та оцінювати художні твори, висловлювати особистісне ставлення до них, аргументуючи свої думки та оцінки, готовність використовувати отриманий досвід у самостійній творчій діяльності [12, с. 158]; цілісний, мотиваційно-рефлекторний художньо-естетичний комплекс, що дає змогу майбутньому фахівцю вільно оперувати художньо-естетичними компетенціями й досягати високих результатів у своїй професійній діяльності [25, с. 249]; інтегральний духовно-естетичний феномен, готовність і здатність особистості мобілізувати персональні ресурси - організовані в систему художні знання, уміння, ставлення, здібності, якості, необхідні для ефективного вирішення художніх завдань у типових і нестандартних ситуаціях, у побудові власної траєкторії життєтворчості [20, с. 6].

Академік І. Зязюн художньо-естетичну компетентність визначав як якість естетичного переживання особистості у сприйнятті мистець- 
кого твору, яка залежить не тільки від рівня мистецьких знань, а ще від специфіки психологічної індивідуальності особи [8, с. 119]. В енциклопедичному словнику «Психологія спілкування» художньо-естетична компетентність трактується як здатність читача, глядача, слухача вичерпувати з художньої тканини твору різні за глибиною і наповненістю змістовно-смислові шари. Ця характеристика відображає загальний рівень естетичного розвитку особистості, іiі досвід спілкування із мистецтвом, а також ступінь творчості, що виявляється в сприйнятті мистецтва. Усе це залежить від знань, когнітивної складності картини світу реципієнта, його здатності до сприйняття багатовимірності й альтернативності, від володіння специфічними «мовами» різних видів, стилів і жанрів мистецтва, що дають змогу «перекласти» зміст мови мистецтва на мову людських емоцій і смислів [21, с. 371].

На думку I. Арябкіної, художньо-естетична компетентність багатокомпонентна і має такі складові компетентності: образотворчо-мовленнєва, вербально-образна, образно-стильова, стратегічна, продуктивно-образна [3, с. 125].

Формуванню образотворчо-мовленнєвої компетентності передує художньо-мовленнєва діяльність, яку ми розуміємо як специфічний вид діяльності, що передбачає здатність сприймати, розуміти й власноруч створювати твори декоративно-ужиткового мистецтва, грамотно користуючись засобами художньої виразності, мовою декоративного мистецтва. Вербально-образна компетентність полягає в умінні вербально інтерпретувати художній образ, пояснити його сенс, зміст $з$ використанням художньо-виразних мовних засобів, художніх метафор під час обговорення твору або роботи над ним. Знанням основних напрямів у декоративному мистецтві, характерних особливостей одного окремого стилю в різних видах декоративного мистецтва, умінням створювати вироби декоративно-ужиткового мистецтва відповідно до заданого стилю характеризується образностильова компетентність. Стратегічна компетентність передбачає уміння бачити педагогічну ситуацію, в якій даний конкретний виріб або художній образ може бути використаний як педагогічний засіб 3 метою вирішення певних виховних завдань; продуктивно-образна здібність до мобільного переходу від репродуктивної до самостійної творчої діяльності в художньому читанні декоративних образів у виконавському процесі. 


\section{Chapter «Pedagogical sciences»}

Художньо-естетичні знання та досвід розвиваються і закріплюються лише через діяльність, вони присутні в будь-якому матеріальному чи художньому виробництві. Історично елементи художньо-естетичної діяльності оформилися в особливу форму свідомості - мистецтво, зокрема декоративно-ужиткове мистецтво, як концентроване вираження художньо-естетичного відношення людини до світу та себе. Нині «народне декоративне мистецтво розглядається як важлива художня цінність, що виконує численні функції - пізнавальну, комунікативну, естетичну та ін. Життя підтверджує, що декоративно-ужиткове мистецтво збагачується новими аспектами філософсько-естетичного звучання, його змістовна краса потрібна людині, а його художньо-культурна, естетична цінність постійно зростає» [23, с. 196]. Декоративно-ужиткове мистецтво є одним 3 дієвих засобів художньо-естетичного розвитку особистості, що відіграє важливу роль у формуванні не тільки естетичного ставлення людини до навколишньої дійсності, а й духовно-моральних якостей.

3 огляду на вищезазначене, художньо-естетична компетентність стано-вить певний обсяг знань з історії виникнення декоративно-ужиткового мистецтва; про види народних ремесел і промислів, художньо-технологічні традиції та досвід самобутніх центрів, визначних майстрів народного мистецтва; становлення, розвиток і значущість мистецтва в сучасному світі, що знайшло відображення в архівних матеріалах, численних дослідженнях етнографів, мистецтвознавців, науковців, педагогів; інформації про засоби композиції, орнаментику та семантику в декоративно-ужитковому мистецтві, принципи їх використання та художнє втілення; уміння та навички художньо-естетичного сприймання, аналізу й інтерпретації творів народного мистецтва, розуміння єдності форми та змісту в декоративному образі; готовність використовувати знання у власній творчій діяльності та художньо-просвітницькій діяльності. Художньо-естетична компетентність відображається у формуванні потреби в отриманні нових знань, розвитку світогляду, сприяє самовираженню в художньо-творчій діяльності.

3 окреслених визначень випливає, що поняття художньо-естетичної компетентності надзвичайно широке, оскільки охоплює мотиваційну, перцептивну, когнітивну, творчо-діяльнісну й рефлексивну сфери структури особистості. Водночас, воно містить дві складові: художню та естетичну компетентності. 
Категорія естетичної компетентності узагальнено визначається як інтег-ральний духовно-естетичний феномен, готовність і здатність особистості мобілізувати персональні ресурси - організовані в систему художні знання, уміння, ставлення, здібності, якості, необхідні для ефективного вирішення художніх завдань у типових і нестандартних ситуаціях, у побудові власної траєкторії життєтворчості [20, с. 6]. Структура естетичної компетентності містить інтегральні характеристики, що синтезують основні компоненти у формі провідних системних якостей, до яких відносимо естетичне світобачення, естетичний смак, естетичний ідеал. Отже, естетична компетентність як найбільш інтегративна характеристика естетичного розвитку особистості забезпечує цілісність, гармонійність розвитку її естетичної сфери в складі загальної культури, сприяє зростанню творчого потенціалу, виявленню іiі неповторності й оригінальності.

У контексті декоративно-ужиткового мистецтва естетичну компетент-ність можна розглядати як систему взаємозв'язаних якостей особистості, які свідчать про іiі готовність до професійної діяльності, синтезуючи знання кано-нів просторової і колірної композиції, орнаментики та семантики тощо, прикладні вміння організовувати зовнішній простір відповідно до правил художньої композиції на основі стійких ціннісних новоутворень особистості у формі художньо-естетичного смаку, креативних здібностей та емоційно-ціннісних настанов. Отже, естетична компетентність педагога у розглядуваному контексті неодмінно пов'язана з його професійними якостями і характеризується високим ступенем полікультурної за своїм змістом гуманітарно-художньої ерудиції; здатністю реалізувати свій естетичний потенціал (знання, уміння, досвід, особистісні якості) на практиці для успішної художньо-професійної діяльності, усвідомлюючи відповідальність за ії̈ результати.

Серед функцій професійної діяльності педагога в галузі декоративно-ужиткового мистецтва провідну роль відіграє здатність до відтворення художньої картини світу, тобто його естетична компетентність 3 відповідною повнотою охоплює художньо-мистецьку та художньо-педагогічну сфери. Саме тому до основних характеристик його професіоналізму слід зарахувати художню компетентність, яку Л. Масол та О. Гайдамака визначають як певну досвідченість особистості в царині мистецтва, здатність до самоорганізації в галузі мистецької діяльності 


\section{Chapter «Pedagogical sciences»}

на основі ціннісних естетичних орієнтацій із метою розвитку власного художньо-творчого потенціалу. На їхню думку, ця категорія має особистісно-діяльнісний та інтегративний характер, оскільки є багатогранним показником результативності мистецької освіти й самоосвіти, що інтегрує всі компоненти: змістовий (знання), процесуальний (уміння), аксіологічний (ціннісні орієнтації), самореалізаційний (самостійність), креативний (творчість) [20, с. 6].

Розглядувані категорії взаємопов'язані, але не тотожні, оскільки «про-блемне поле естетичного значно ширше, ніж у мистецтва. Поняття «естетичне» відображає те загальне, що характерне для прекрасного і потворного, піднесеного і низького, гармонійного і хаотичного. А поняття «художнє», як відмічають А. Лосєв і В. Шестаков, є «прикметником від іменника мистецтво» [7, с. 134].

Узагальнення існуючих підходів до визначення сутності художньо-естетичного розвитку особистості та опрацювання наукових джерел дає підстави визначити художньо-естетичну освіту як організований процес формування творчо активної особистості, що передбачає засвоєння сукупності полікультурних, поліхудожніх і партисипативних знань, в основі яких лежать світоглядні настанови відношення до мистецтва та художньої творчості. У свою чергу, художньо-естетичну компетентність можна розглядати як систему внутрішніх засобів регуляції художньо-естетичних дій, в яку безпосередньо входять художньо-естетичні знання, вміння і досвід, естетична орієнтованість, заснована на знаннях, досвіді студента та вільному володінні художньо-естетичними засобами. Підсумовуючи вищезазначене, визначаємо художньо-естетичну компетентність як професійно-особистісний багатовимірний феномен, який має метаструктуру та характеризується здатністю створювати власні твори декоративно-ужиткового мистецтва, готовністю сприймати здобутки світового та вітчизняного народного мистецтва, що грунтується на усвідомленні народної культури та творчості, художньому смаку, мистецьких знаннях та оцінних судженнях.

Розвиток професіоналізму та формування у майбутніх учителів художньо-естетичної компетентності засобами декоративно-ужиткового мистецтва передбачають їхню художньо-педагогічну й художньо-технічну педагогічну підготовку. Науковець О. Каленюк зазначає, що художньо-педагогічна освіта - дидактичний процес формування і засвоєння фахових знань, навичок, поглядів, мислення в системі підго- 
товки вчителя в різних сферах образотворчої (мистецької) діяльності [11, с. 13]. Іншими словами, художньо-педагогічна діяльність учителя в галузі декоративно-ужиткового мистецтва полягає у поєднанні педагогічної та мистецької діяльності, розв'язанні навчально-виховних завдань, реалізації освітніх цілей засобами мистецької педагогіки. За Л. Ейвас, художньо-технічна педагогічна освіта - освіта, що спрямовується на надання необхідних технічних знань, умінь і навичок, оволодіння майбутніми фахівцями технічним мисленням шляхом вивчення художніх технік обробки матеріалів, виготовлення творів декора-тивно-ужиткового мистецтва та реалізації дизайнерських проектів, а також забезпечує необхідними методичними знаннями [6, с. 19].

\section{4. Структурні компоненти художньо-естетичної компетентності}

Художньо-естетична компетентність майбутнього вчителя як особистісне утворення є єдиною, цілісною структурою, яка не може існувати без компонентів, що до неї входять; дає можливість майбутньому педагогу усвідомити себе суб'єктом художньо-естетичної діяльності; сприяє удосконаленню в професійному та особистісному плані. Враховуючи визначення дефініції «професійна компетентність педагога», зміст поняття художньо-естетичної компетентності педагога в галузі декоративно-ужиткового мистецтва та узагальнюючи думки науковців щодо структури компетентності фахівців мистецьких та педагогічних спеціальностей, вважаємо, що основними структурними компонентами художньо-естетичної компетентності педагога в галузі декоративно-ужиткового мистецтва є: когнітивний, мотиваційно-ціннісний, діяльнісно-практичний, рефлексивний, комунікативний, естетичний.

Когнітивний компонент окреслює обізнаність особистості щодо ціннос-тей рідного етносу, що втілюються у народних традиціях декоративно-ужиткового мистецтва, передбачає володіння комплексом художньо-естетичних знань; сприйняття декоративного мистецтва як суспільного явища і системи, що постійно розвивається; усвідомлення зв'язку декоративно-ужиткового мистецтва з мисленням, культурою i суспільним розвитком народу. Когнітивний компонент тісно пов'язаний $з$ певною предметною діяльністю особистості.

Когнітивний компонент художньо-естетичного досвіду охоплює не тільки знання про історію, закони, принципи та технології розгляду- 
ваного мистецтва, а й розгалужену систему знань про інші види мистецтва, які узагальнюють і синтезують найсуттєвіші та найзначніші проблеми людського життя. Закріпленню у свідомості різнопланових мистецьких знань сприяє емоційна забарвленість декоративно-художньої інформації, яка передбачає почуттєвий рівень реагування, що розширює межі пізнання навколишнього світу, допомагає усвідомити його багатство. Освоєння студентом мистецьких знань має бути також аналітичним за своїм характером, що сприятиме повноцінному формуванню художньо-естетичного досвіду, опануванню необхідними прийомами і способами інтерпретації творів декоративно-ужиткового мистецтва. Мистецькі знання впливають на формування уміння виділяти в декоративно-ужитковому мистецтві соціально значущих аспектів, аналізувати особливості змісту та художньої форми його творів.

Мотиваційно-ціннісний компонент передбачає наявність мотивів, цілей, потреб у професійному навчанні, вдосконаленні, самовихованні, саморозвитку, ціннісних установок, що актуалізують необхідність формування художньо-естетичної компетентності засобами декоративно-ужиткового мистецтва та стимулюють художньо-творчий вияв особистості в професійній діяльності, зростання їі майстерності, забезпечують розуміння декоративно-ужиткового мистецтва у контексті культурного розвитку суспільства, відображає вмотивованість особистості до засвоєння, збереження та примноження традицій власного етносу. Він припускає наявність інтересу до професійної діяльності, який характеризує потребу людини в знаннях, в оволодінні ефективними способами організації професійної діяльності. Також ціннісно-мотиваційний компонент включає мотиви здійснення педагогічної діяльності, спрямованість на передачу суми знань і розвиток особистості учнів.

У загальному розумінні основою мотивації $\epsilon$ певна потреба, яка є витоком будь-якої активності. На переконання психолога С. Каверіна, потреба у творчій діяльності є вищою потребою, що, відповідно, позначає вищий ступінь розвитку особистості. Провідними мотивами творчості, на його думку, є: допитливість (пізнавальні та дослідницькі мотиви); мотиви особистої зацікавленості (самоствердження); вищі соціальні мотиви (принести користь суспільству) [9, с. 125].

Однією з основних складових мотивації людської діяльності $є$ інтерес, що відіграє конструктивно-творчу роль у суспільному роз- 
витку. Поміж розмаїття інтересів, мистецький інтерес становить мотиваційний чинник творчості, основу творчої діяльності. Зміст основних мотивацій людини відображають цінності, зокрема цінності національної культури, вікових традицій українського народу. Ціннісна свідомість учителя як відображення значення смислів творів декоративно-ужиткового мистецтва для нього пронизує увесь практичний базис його педагогічної діяльності. Одна 3 найважливіших якостей майбутнього вчителя в галузі декоративно-ужиткового мистецтва полягає в умінні правильно визначати естетичні цінності творів розглядуваного мистецтва й аргументовано пояснювати своє ставлення до них. Учитель має навчити сприймати, оцінювати й усвідомлювати ціннісні смисли творів декоративно-ужиткового мистецтва.

Відтак, включення майбутніх учителів до художньо-естетичної діяльності засобами декоративно-ужиткового мистецтва є продуктивним, оскільки воно виконує специфічну, властиву лише йому функцію - розкриває перед особистістю світ реальної краси, яка приносить естетичну насолоду та відіграє важливу роль у формуванні переконань, поглядів, норм і правил поведінки, є джерелом духовного багатства, стимулом активного життя. Декоративно-ужиткове мистецтво постає могутнім засобом зв'язку поколінь, через задоволення художніх потреб реалізується соціальне призначення мистецтва. Цінність будьякого мистецтва, зокрема й декоративно-ужиткового, визначається багатством засобів, за допомогою яких втілюються певні ідеї та реалізується естетичне призначення ужиткових речей. Від співвідношення їх елементів, від їх порядку, рівноваги, гармонії залежить можливість їхього подальшого розвитку.

3 філософського погляду, власне «матеріальним або духовним може бути носій цінності, а не сама цінність, оскільки вона є відношення даного носія до суб'єкта, його значення для суб'єкта» [10, с. 55]. Психолог С. Рубінштейн цінності позиціонує як такі, що мають за основу взаємозв'язок довкілля і світу людини та виражаються у тому, що значуще створює людина в історичному процесі [22, с. 36]. У цьому контексті актуальним $є$ питання про напрями розвитку художньої картини світу як системи, спрямованої на концентрацію тих світоглядних основ і духовно-ціннісних смислів, які отримали відображення у творах декоративно-ужиткового мистецтва. 


\section{Chapter «Pedagogical sciences»}

Сутність художньо-естетичних цінностей виявляється у взаємозв'язку інтересів, потреб, здібностей, смаків, установок особистості; у відображенні певного виду ціннісно-орієнтаційної діяльності, зумовленої рівнем розвитку естетичних відношень. Тому цілеспрямована ціннісна регуляція в процесі навчання майбутнього вчителя декоративно-ужиткового мистецтва вимагає проникнення у сутність особистості, структуру та динаміку іiі мотивацій, потреб, смаків і установок, у сферу створення й відбору цінностей.

Діяльнісно-практичний компонент віддзеркалює здатність особистості пізнавати та зберігати народні традиції свого етносу, а також діяльнісно-практичні реалії їх відтворення і творчої передачі на основі набутих знань та умінь; дає змогу використовувати наявні професійні знання, уміння і навички для реалізації завдань професійної діяльності. Він тісно пов'язаний з розвитком практичних навичок з декоративно-ужиткового мистецтва, що передбачають оволодіння всіма видами художньо-естетичної діяльності, яку можна визначити як духовно-практичну (створення засобами декоративного мистецтва нових суспільно значущих матеріальних і духовних цінностей) та духовну (естетичне споглядання, естетичне сприймання, естетичне судження тощо) діяльність (художньо-прикладною графікою, рисунком, живописом, декоративно-прикладною творчістю, декоративною пластикою, етнологічною скульптурою).

Організаційно-педагогічну основу діяльнісно-практичного компонента складають технологія та методика, які розширюють і поглиблюють професійну свідомість, здійснюють оптимальний вибір форм спілкування в освітніх системах «викладач - твір декоративно-ужиткового мистецтва - студент».

Рефлексивний компонент свідчить про здатність особистості до самооцінки ставлення до мистецьких традицій свого та інших етносів; передбачає вміння аналізувати хід і результати власної практичної (професійно-творчої, науково-дослідної, художньо-естетичної) діяльності, об' єктивно оцінювати себе, свій рівень мистецької майстерності (самоконтроль, самоаналіз, самооцінка).

Рефлексивне ставлення людини до власної діяльності є однією 3 найважливіших умов глибшого ii усвідомлення, критичного аналізу та конструктивного удосконалення. Рефлексія знаходить своє вираження у так званій нормальній подвійності свідомості, коли індивід по 
відношенню до самого себе одночасно виступає і як об'єкт рефлексії («Я-виконавець»), і як їі суб’єкт («Я-контролер»), що регулює власні дії та вчинки. Рефлексивний аналіз діяльності не є замкнутим у якомусь чисто «індивідуальному просторі» самосвідомості процесом, навпаки, здатність людини рефлексивно поставитися до самої себе і до своєї діяльності - є результатом освоєння (інтеріоризації) особистістю соціальних відносин між людьми. Лише під час взаємодії з іншими людьми, коли людина намагається зрозуміти думки та дії іншого, вона здатна рефлексивно поставитися і до самої себе.

Під час декоративно-прикладної діяльності студентів передбачається вивести особистість на такий рівень самосвідомості, де безперервне творче самовдосконалення буде природним станом майбутнього фахівця. Вихід на визначений рівень самосвідомості неможливий без знання й володіння рефлексивними процесами. Високий рівень самосвідомості стимулює творчу активність та опосередкує формування внутрішніх мотивів і цінностей.

Таким чином, рефлексія майбутнього фахівця як його внутрішня психічна діяльність спрямована на самопізнання й осмислення ним свого духовного світу, власних дій і станів, ролі і місця у праці. Самопізнання є передумовою самовдосконалення, власне, того, до чого викладач має невпинно готувати студентів.

Комунікативний компонент демонструє здатність особистості до самоспілкування у пізнанні традицій декоративно-ужиткового мистецтва та до мистецького діалогу з представниками свого та інших етносів на засадах толерантності, взаєморозуміння, взаємоповаги у процесі пізнання народних традицій.

Естетичний компонент у контексті художньо-естетичної компетентності слід прийняти як системоутворювальний, оскільки саме він $€$ інтегратором решти компонентів у засвоєнні традицій декоративно-ужиткового мистецтва. Цей компонент полягає в тому, що естетична потреба, вимагаючи задоволення, створює установку на пошук особистісних шляхів її реалізації. У процесі естетичного сприймання та творення образів виникає результат діяльності - конкретно-чуттєвий твір, який переживається суб'єктом, а також оцінюється відповідно до уявлень про естетичний ідеал. Естетичні переживання й оцінювання породжують естетичне ставлення до дійсності, яке дає поштовх до більш творчої діяльності. 


\section{Chapter «Pedagogical sciences»}

Художньо-естетична діяльність збагачує емоційну сферу студентів, формує ціннісні орієнтації в галузі декоративно-ужиткового мистецтва. Вона сприяє генеруванню естетичних ідей, збагаченню їх змістової основи, допомагає знаходити способи та прийоми художньо-образної виразності. Пізнавальна й оцінна підсистеми художньо-естетичної діяльності майбутнього вчителя, що представляють в ії структурі пізнавальний та ціннісний компоненти художньо-естетичного досвіду, надають духовного змісту декоративно-ужитковому мистецтву.

\section{5. Висновок}

Професійна підготовка вчителя нині розглядається як складна поліфункціональна відкрита педагогічна система, спрямована на формування професійно важливих знань, умінь, навичок, особистісних якостей вчителя, здатного працювати в системі, що характеризується взаємодією різних культур, готового до професійної діяльності в межах полікультурного освітнього простору на засадах суб'єкт-суб'єктної взаємодії, діалогу культур та індивідуальної моральної відповідальності в мультикультурному суспільстві [26]. У сучасних умовах державна політика у сфері освіти грунтується на засадах нерозривного зв'язку із світовою та національною історією, культурою, національними традиціями; виховання патріотизму, поваги до культурних цінностей українського народу, його історико-культурного надбання і традицій.

3 огляду на вищезазначене, цілком слушним є звернення до розгляду проблеми формування у майбутніх учителів художньо-естетичної компетент-ності засобами декоративно-ужиткового мистецтва. За цих умов особливого значення набуває технологія формування професійних знань у контексті фахової підготовки особистості майбутнього вчителя на основі наповнення культурологічним змістом всіх складових педагогічного фундаменту, актуальних для сьогодення.

Поняття художньо-естетичної компетентності охоплює мотиваційну, пе-рцептивну, когнітивну, творчо-діяльнісну й рефлексивну сфери структури особистості. Його ми визначаємо як професійно-особистісний багатовимірний феномен, який має метаструктуру та характеризується здатністю створювати власні твори декоративно-ужиткового мистецтва, готовністю сприймати здобутки світового та вітчизняного народного мистецтва, що грунтується на 
усвідомленні народної культури та творчості, художньому смаку, мистецьких знаннях та оцінних судженнях. Художньо-естетична компетентність майбутнього вчителя у галузі декоративно-ужиткового мистецтва як особистісне утворення є єдиною, цілісною структурою, основними компонентами якої $є$ : когнітивний, мотиваційно-ціннісний, діяльнісно-практичний, рефлексивний, комунікативний, естетичний.

Перспективу подальших досліджень вбачаємо у визначенні педагогічних умов, розгляді педагогічних технологій формування художньо-естетичної компетентності майбутніх учителів засобами декоративно-ужиткового мистецтва.

\section{Список літератури}

1. Абульханова-Славская К. А. Деятельность и психология личности / К.А. Абульханова-Славская ; [отв. ред. В.А. Лекторский]. - М.: Наука, 1980. $335 \mathrm{c}$.

2. Андрієвська В.В. Професійна компетенція: теорія і практика їі оцінки на Заході / В.В. Андрієвська // Науково-методичне забезпечення діяльності сучасної професійної школи. - К., 1994. - Ч. 1. - С. 25-29.

3. Арябкина И.В. Формирование культурно-эстетической компетентности учителя младшей школы на основе личностно-ориентированного подхода: теоретические аспекты / И.В. Арябкина. - Москва: Кальвария, 2010. - 240 с.

4. Бібік Н. Компетентнісний підхід: рефлексивний аналіз застосування / Н. Бібік // Компетентнісний підхід у сучасній освіті: світовий досвід та українські перспективи / за заг. ред. О. Овчарук. - К.: Вид-во К.І.С., 2004. - С. 47-53.

5. Деркач А.А. Акмеология: пути достижения вершин профессионализма / А.А. Деркач, Н.В. Кузьмина. - М.: РАУ, 1993. - 23 с.

6. Ейвас Л.Ф. 3 досвіду підготовки вчителя декоративно-прикладного мистецтва в Україні: [монографія] / Л.Ф. Ейвас. - Кривий Ріг: Видавець ФОП Чернявський Д.О., 2016. - 136 с.

7. Зязюн І.А. Естетичний досвід особи. Формування і сфери вияву / І.А. Зязюн. - К.: Вища школа, 1976. - 1 ч. -174 с.

8. Зязюн І.А. Учитель мистецьких дисциплін у дискурсі педагогічної майстерності: [монографія] / I.А. Зязюн, Г.Г. Філіпчук, О.М. Отич та ін. Бердянськ: Видавець Ткачук О.В., 2013. - 334 с.

9. Каверин С.Б. О психологической классификации потребностей / С.Б. Каверин // Вопросы психологии. - 1987. - № 5. - С. 121-129.

10. Каган М.С. Человеческая деятельность: опыт системного анализа / М.С. Каган. - М.: Политиздат, 1974. - 398 с.

11. Каленюк О.М. Дидактичні засади формування фахових знань у майбутніх учителів образотворчого мистецтва: автореф. дис. на здобуття наук. ступеня канд. пед. наук: спец. 13.00.09 «Теорія навчання» / О.М. Каленюк. Луцьк, 2005. - 20 с. 


\section{Chapter «Pedagogical sciences»}

12. Карасев Ю.В. Особенности живописи на пленэре / Ю.В. Карасев // Фундаментальные исследования. - 2005. - № 1. - С. 92-93.

13. Кравченко Я. Димлене диво / Я. Кравченко // Пам'ятки України. 1989. - № 1. - С. 96-102.

14. Лутаєнко В.С. Естетика мислення / В.С. Лутаєнко. - Київ: Мистецтво, 1974. - 243 c.

15. Мандель Б.Р. Интеллектуальная игра: на перекрестке научных дис-циплин / Б.Р. Мандель // Педагогика. - 2006. - № 7. - С. 44-48.

16. Марущак О.В. Духовно-естетичне виховання учнів ЗНЗ засобами гончарного мистецтва / О.В. Марущак, І.В. Савчук, С.О. Бойчук // Актуальні проблеми підготовки вчителя трудового навчання та технологій середньої школи: теорія, досвід, проблеми: зб. наук. пр. - Випуск I. - Вінниця: ТОВ «Меркьюрі Поділля», 2018. - С. 221-225.

17. Марущак О.В. Методичні аспекти етнокультурного виховання учнів старшої школи засобами ДУМ / О.В. Марущак, А.В. Кашуба, Я.I. Магдич // Актуальні проблеми підготовки вчителя трудового навчання та технологій середньої школи: теорія, досвід, проблеми: зб. наук. пр. - Випуск I. - Вінниця: ТОВ «Меркьюрі Поділля», 2018. - С. 228-232.

18. Марущак О.В. Термінологічні аспекти формування професійної компетентності майбутнього фахівця / О.В. Марущак, В.П. Король // Сучасні інформаційні технології та інноваційні методики навчання у підготовці фахівців: методологія, теорія, досвід, проблеми: зб. наук. пр. - Випуск 37. - КиївВінниця: ТОВ фірма «Планер», 2014. - С. 421-427.

19. Масол Л.М. Загальна мистецька освіта: теорія і практика: [монографія] / Л.М. Масол. - К.: Промінь, 2006. - 431 с.

20. Мастера искусства об искусстве: избранные отрывки из писем, дневников, речей и трактатов: [в 7 т.] / под общ. ред. Д. Аркина, Б. Терновца - М.: Искусство, 1967. - Т. 2. -622 с.

21. Психология общения: энциклопедический словарь / [под общ. ред. А.А. Бодалева]. - М.: Изд-во «КогитоЦентр», 2011. - 600 с.

22. Рубинштейн С.Л. Человек и мир / С.Л. Рубинштейн // Проблемы общей психологии. - М.: АПН РСФСР, 1976. - С. 253-381.

23. Савчук I.В. Декоративно-ужиткове мистецтво як чинник формування естетичних смаків сучасної молоді / I.В. Савчук, А.В. Кашуба // Актуальні проблеми підготовки вчителя трудового навчання та технологій середньої школи: теорія, досвід, проблеми: зб. наук. пр. - Випуск I. - Вінниця: ТОВ «Меркьюрі Поділля», 2018. - С. 195-198.

24. Хуторской А. Деятельность как содержание образования / А. Хуторской // Народное образование. - 2003. - № 8. - С. 107-114.

25. Чернышева С.А. Роль проектных методов в формировании художественно-творческой компетенции у студентов педагогического колледжа / С.А. Чернышева // Молодой ученый. - 2014. - № 18. C. 674-676.

26. Якса Н.В. Професійна підготовка майбутніх вчителів: теорія і методика міжкультурної взаємодії в умовах Кримського регіону: [монографія] / Н.В. Якса. - Житомир: ЖДУ ім. І. Франка, 2008. - 568 с. 


\section{References:}

1. Abul'khanova-Slavskaya K.A. (1980). Deyatel'nost' i psikhologiya lichnosti [Activity and personality psychology]. V.A. Lektorskiy (Ed.). Moskva: Nauka, 335 p. (in Russian)

2. Andriievska V.V. (1994). Profesiina kompetentsiia: teoriia i praktyka yii otsinky na Zakhodi [Professional competence: theory and practice of its assessment in the West]. Naukovo-metodychne zabezpechennia diialnosti suchasnoi profesiinoi shkoly (Part 1). Kyiv, pp. 25-29. (in Ukrainian)

3. Aryabkina I.V. (2010). Formirovanie kul'turno-esteticheskoy kompetentnosti uchitelya mladshey shkoly na osnove lichnostno-orientirovannogo podkhoda: teoreticheskie aspekty [Formation of cultural and aesthetic competence of a primary school teacher on the basis of a student-centered approach: theoretical aspects]. Moskva: Kal'variya, 240 p. (in Russian)

4. Bibik N. (2004). Kompetentnisnyi pidkhid: refleksyvnyi analiz zastosuvannia [Competency approach: reflexive application analysis]. Kompetentnisnyi pidkhid u suchasnii osviti: svitovyi dosvid ta ukrainski perspektyvy [Competency approach in contemporary education: world experience and Ukrainian perspectives]. O. Ovcharuk (Ed.). Kyiv: K.I.S, pp. 47-53. (in Ukrainian)

5. Derkach A.A., Kuz'mina N.V. (1993). Akmeologiya: puti dostizheniya vershin professionalizma [Acmeology: ways to reach the heights of professionalism]. Moskva: RAU, 23 p. (in Russian)

6. Eivas L.F. (2016). Z dosvidu pidhotovky vchytelia dekoratyvnoprykladnoho mystetstva $\mathrm{v}$ Ukraini [From the experience of preparing the teacher of decorative and applied art in Ukraine]. Kryvyi Rih: FOP Cherniavskyi D.O., 136 p. (in Ukrainian)

7. Ziaziun I.A. (1976). Estetychnyi dosvid osoby. Formuvannia i sfery vyiavu [Aesthetic experience of the person. Formation and spheres of manifestation]. (Part 1). Kyiv: Vyshcha shkola, 174 p. (in Ukrainian)

8. Ziaziun I.A., Filipchuk H.H., Otych O.M. ta in. (2013). Uchytel mystetskykh dystsyplin u dyskursi pedahohichnoi maisternosti [Teacher of artistic disciplines in the discourse of pedagogical skill]. Berdiansk: Vydavets Tkachuk O.V., 334 p. (in Ukrainian)

9. Kaverin S.B. (1987). O psikhologicheskoy klassifikatsii potrebnostey [On the psychological classification of needs]. Voprosy psikhologii, no. 5, pp. 121-129. (in Russian)

10. Kagan M.S. (1974). Chelovecheskaya deyatel'nost': opyt sistemnogo analiza [Human activities: systems analysis experience]. Moskva: Politizdat, 398 p. (in Russian)

11. Kaleniuk O.M. (2005). Dydaktychni zasady formuvannia fakhovykh znan u maibutnikh uchyteliv obrazotvorchoho mystetstva [Didactic basis for the formation of professional knowledge of future teachers of fine arts]. Extended abstract of candidate's thesis. Lutsk, 20 p. (in Ukrainian)

12. Karasev Yu.V. (2005). Osobennosti zhivopisi na plenere [Features of painting in the open air]. Fundamental'nye issledovaniya, no. 1, pp. 92-93. (in Russian)

13. Kravchenko Ya. (1989). Dymlene dyvo [Smoker's miracle]. Pamiatky Ukrainy, no. 1, pp. 96-102. (in Ukrainian) 


\section{Chapter «Pedagogical sciences»}

14. Lutaienko V.S. (1974). Estetyka myslennia [Aesthetics of thinking]. Kyiv: Mystetstvo, 243 p. (in Ukrainian)

15. Mandel' B.R. (2006). Intellektual'naya igra: na perekrestke nauchnykh distsiplin [Intellectual game: at the crossroads of scientific disciplines]. Pedagogika, no. 7, pp. 44-48. (in Russian)

16. Marushchak O.V., Savchuk I.V., Boichuk S.O. (2018). Dukhovnoestetychne vykhovannia uchniv ZNZ zasobamy honcharnoho mystetstva [Spiritual and aesthetic upbringing of students of the State Higher Educational Establishment by means of pottery art]. Aktualni problemy pidhotovky vchytelia trudovoho navchannia ta tekhnolohii serednoi shkoly: teoriia, dosvid, problemy [Actual problems of teacher training of labor training and technologies of secondary school: theory, experience, problems]. (Issue 1). Vinnytsia: TOV «Merkiuri Podillia», pp. 221-225. (in Ukrainian)

17. Marushchak O.V., Kashuba A.V., Mahdych Ya.I. (2018). Metodychni aspekty etnokulturnoho vykhovannia uchniv starshoi shkoly zasobamy DUM [Methodical aspects of ethnocultural education of high school students by means of decorative and applied arts]. Aktualni problemy pidhotovky vchytelia trudovoho navchannia ta tekhnolohii serednoi shkoly: teoriia, dosvid, problemy [Actual problems of teacher training of labor training and technologies of secondary school: theory, experience, problems]. (Issue 1). Vinnytsia: TOV «Merkiuri Podillia», pp. 228-232. (in Ukrainian)

18. Marushchak O.V., Korol V.P. (2014). Terminolohichni aspekty formuvannia profesii-noi kompetentnosti maibutnoho fakhivtsia [Terminological aspects of forming the professional competence of a future specialist]. Suchasni informatsiini tekhnolohii ta innovatsiini metodyky navchannia $u$ pidhotovtsi fakhivtsiv: metodolohiia, teoriia, dosvid, problemy [Modern information technologies and innovative methods of training in the training of specialists: methodology, theory, experience, problems]. (Issue 37). Kyiv-Vinnytsia: TOV firma «Planer», pp. 421-427. (in Ukrainian)

19. Masol L.M. (2006). Zahalna mystetska osvita: teoriia i praktyka [General artistic education: theory and practice]. Kyiv: Promin, 431 p. (in Ukrainian)

20. Arkina D., Ternovtsa B. (Ed.). (1967). Mastera iskusstva ob iskusstve: izbrannye otryvki iz pisem, dnevnikov, rechey i traktatov [Artists on Art: Selected Passages from Letters, Diaries, Speeches, and Treatises]. (Vols. 2). Moskva: Yskusstvo, 622 p. (in Russian)

21. Bodalev A.A. (Ed.). (2011). Psikhologiya obshcheniya: entsiklopedicheskiy slovar' [Psychology of communication: encyclopedic dictionary]. Moskva: «KogitoTsentr», 600 p. (in Russian)

22. Rubinshteyn S.L. (1976). Chelovek i mir [Man and the world]. Problemy obshchey psikhologii [Problems of general psychology]. Moskva: APN RSFSR, pp. 253-381. (in Russian)

23. Savchuk I.V., Kashuba A.V. (2018). Dekoratyvno-uzhytkove mystetstvo yak chynnyk formuvannia estetychnykh smakiv suchasnoi molodi [Decorative and applied art as a factor in the formation of aesthetic tastes of modern youth]. Aktualni problemy pidhotovky vchytelia trudovoho navchannia ta tekhnolohii serednoi shkoly: teoriia, dosvid, problemy [Actual problems of teacher training of labor 
training and technologies of secondary school: theory, experience, problems]. (Issue 1). Vinnytsia: TOV «Merkiuri Podillia», pp. 195-198. (in Ukrainian)

24. Khutorskoy A. (2003). Deyatel'nost' kak soderzhanie obrazovaniya [Activity as educational content]. Narodnoe obrazovanie, no. 8, pp. 107-114. (in Russian)

25. Chernysheva S.A. (2014). Rol' proektnykh metodov v formirovanii khudozhestvenno-tvorcheskoy kompetentsii $\mathrm{u}$ studentov pedagogicheskogo kolledzha [The role of design methods in the formation of artistic and creative competence among students of the pedagogical college]. Molodoy uchenyy, no. 18, pp. 674-676. (in Russian)

26. Yaksa N.V. (2008). Profesiina pidhotovka maibutnikh vchyteliv: teoriia i metodyka mizhkulturnoi vzaiemodii v umovakh Krymskoho rehionu [Professional training of future teachers: theory and method of intercultural cooperation in the Crimean region]. Zhytomyr: ZhDU im. I. Franka, 568 p. (in Ukrainian) 